\title{
Analisis Transparansi dan Akuntabilitas dalam Pengelolaan Alokasi Dana Desa di Desa Wakan Lombok Timur
}

\author{
Siti Utami Rinjani \\ Universitas Hamzanwadi \\ utamirinjani227@gmail.com
}

\begin{abstract}
Abstrak
Penelitian ini bertujuan untuk mengetahui bagaimana penerapan transparansi dan akuntabilitas dalam pengelolaan Alokasi Dana Desa (ADD) di Desa Wakan Lombok Timur yang terdiri dari tiga tahap yakni, tahap perencanaan, tahap pelaksanaan, dan tahap pertanggungjawaban. Metode yang digunakan adalah metode deskriptif kualitatif. Analisis data dilakukan dengan model Miles dan Humberman. Hasil penelitian ini menunjukkan bahwa untuk tahap perencanaan dan pelaksanaan dalam pengelolaan ADD di Desa Wakan Kecamatan Jerowaru Kabupaten Lombok Timur sudah sesuai sebagaimana dengan prosedur yang berlaku. Pengelolaanya sudah dilaksanakan sesuai dengan asas transparansi dan akuntabilitas. Ada sebagian dari masyarakat yang masih mengeluh kepada pemerintah Desa bahwa pihak Pemerintah Desa belum sepenuhnya menginformasikan kepada masyarakat Desa Wakan dalam hal pengelolaan ADD. Kemudian dalam tahap pertanggungjawaban dalam Pengelolaan ADD di Desa Wakan Lombok Timur secara fisik dan administrasi pemerintah desa Wakan sudah cukup baik karena sudah sesuai dengan peraturan dan perundang-undangan.
\end{abstract}

Kata Kunci: Transparansi, Akuntabilitas, Dana Desa

\begin{abstract}
This researcher aims to find out how the implementation of Transparency and Accountability in the management of Village Fund Allocation (ADD) in Wakan Village, East Lombok, which consists of three stages, namely, the planning stage, the implementation stage, and the accountability stage. The method used is descriptive qualitative method. Data analysis was carried out using the Miles and Humberman model. The results this study indicate that for the planning and implementation stages in the management of ADD in Wakan Village, Jerowaru District, East Lombok Regency, it is in accordance with applicable procedures. The management has been carried out in accordance with the principles of transparency and accountability. There are some people who still complain to the Village government that the Village Government has not fully informed the Wakan Village community regarding the management of ADD. Then in the accountability stage in the Management of ADD in Wakan Village, East Lombok, physically and the administration of the Wakan Village Government is quite good because it is in accordance with the rules and regulations.
\end{abstract}

Keywords: Transparency, Accountability, Village Fund 


\section{Pendahuluan}

Akuntansi keuangan (pemerintahan) daerah di Indonesia merupakan salah satu bidang dalam akuntansi sekror publik yang dapat perhatian besar dari berbagai pihak semenjak reformasi tahun 1998. Hal tersebut di sebabkan oleh adanya kebijakan baru dari pemerintah Republik Indonesia yang "mereformasi” berbagai hal, termasuk pengelolaan keuangan daerah (Halim, 2007). Seiring berjalannya waktu, akuntansi pemerintah berkembang semakin pesat seiring dengan adanya era baru dalam pelaksanaan otonomi daerah dan desentralisasi fiskal. Pelaksanaan otonomi daerah ditetapkan dalam Tap MPR No.XV/MPR/1998 tentang Penyelenggaraan Otonomi Daerah (MPR, 1998).

Ketetapan MPR tersebut menjadi landasan dikeluarkannya UU No. 22 Tahun 1999 yang sudah direvisi menjadi UU No. 23 Tahun 2004 tentang Pemerintahan Daerah. Kemudian UU No. 25 tahun 1999 direvisi menjadi UU No. 32 Tahun 2004 tentang Perimbangan Keuangan antara Pemerintah Pusat dan Pemerintahan Daerah. Tidak hanya itu, pemerintah mengeluarkan peraturan perundang-undangan terbaru tentang otonomi daerah yaitu Undang-undang Republik Indonesia No. 9 Tahun 2015 tentang perubahan atas Undang-undang No. 23 Tahun 2014 tentang pemerintahan daerah.

Peraturan perundang-undangan No. 9 Tahun 2015 yang terbaru tersebut berbicara tentang Pemerintah Daerah, dimana kepala daerah sebagai unsur penyelenggara. Pemerintah Daerah yang memimpin pelaksanaan urusan pemerintahan yang menjadi wewenang daerah otonomi. UU tersebut berisi mengenai perlunya dilaksanakan Otonomi Daerah, sehingga UU tersebut sering disubut dengan UU Otonomi Daerah. Otonomi daerah adalah wewenang yang dimiliki Daerah Otonomi untuk mengatur dan mengurus masyarakatnya menururt kehendak sendiri berdasarkan aspirasi masyarakat, sesuai dengan peraturan perundang-undangan yang berlaku.

Dengan adanya UU No. 9 Tahun 2015 tentang pemerintahan daerah tersebut, maka perubahan yang terjadi adalah penegasan dari pembantu tugas kepala daerah, yaitu wakil kepala daerah. Di dalam UU ini juga diatur segala tugas dari kepala daerah yang baru dan berbagai ketentuan baru yang lain. Dengan disahkannya UU Nomor 6 Tahun 2014 tentang Desa, diharapkan dengan segala kepentingan dan kebutuhan masyarakat desa dapat diakomodir dengan lebih baik. Pemberian kesempatan yang lebih besar bagi desa untuk mengurus tata pemerintahanya sendiri serta pemerataan pelaksanaan pembangunan diharapkan dapat meningkatkan kesejahteraan dan kualitas hidup masyarakat desa, 
sehingga permasalahan seperti kesenjangan antar wilayah, kemiskinan, dan masalah sosial budaya lainnya dapat diminimalisir.

UU Nomor 6 Tahun 2014 beserta peraturan pelaksanaanya telah mengamanatkan pemerintah desa untuk lebih mandiri dalam mengelola pemerintahan dan berbagai sumber daya alam yang dimiliki, termasuk didalamnya pengelolaan keuangan dan kekayaan milik desa. Untuk meningkatkan pembangunan daerah, dalam APBN 2018 pemerintah mengalokasikan dana Rp. 706,16 triliun untuk transfer ke daerah dan Rp. 60 triliun untuk alokasi dana desa (ADD) (Databoks, 2019).

Sejak Dana Desa dijalankan tahun 2015, alokasi tiap tahun selalu naik, yaitu Rp 20,8 triliun tahun 2015, Rp. 47 triliun tahun 2016, dan Rp. 60 triliun tahun 2017 dan 2018 yang tersebar keseluruh desa di Indonesia. Meskipun demikian banyak kalangan yang memandang pemerataan dalam wujud Dana Desa adalah program yang bagus, dengan besarnya anggaran yang diberikan seringkali disalah gunakan oleh kepala daerah setelah sejumlah kepala daerah ditangkap karena dugaan penyelewengan Dana Desa. Dengan besarnya anggaran yang diberiakan pemerintah pusat kepada pemerintah daerah khususnya pemerintah desa diperlukan asas transparansi, akuntabilitas, dan transparansi dalam mengelola alokasi dana tersebut guna mengantisipasi penyelewengan untuk mewujudkan kesejahteraan masyrakat dapat terealisasi dengan baik.

Menurut Peraturan Peraturan pemerintah Nomor 43 tahun 2014 tentang Peraturan Pelaksanaan Undang-undang Nomor 6 tahun 2014 tentang Desa menjelaskan bahwa ADD adalah dana perimbangan yang diterima Kabupaten/Kota dalam anggaran pendapatan dan belanja daerah Kabupaten/Kota setelah dikurangi dana alokasi khusus. Undang-undang Nomor 6 tahun 2014 menyatakan bahwa paling sedikit 10\% (sepuluh perseratus) dari dana perimbangan APBN (Bupati Lombok Timur, 2018; Bupati Lombok Timur, 2013; Mendagri, 2018; Mendagri 2007; Menkeu, 2016; Presiden, 2014).

Untuk memahami good governance adalah harus memahami atas prinsip-prinsip di dalamnya. Bertolak dari prinsip-prinsip ini akan didapatakan tolak ukur kinerja suatu pemerintahan (Andrianto, 2007). Baik-buruknya pemerintahan biar dinilai dari prinsip utama yakni akuntabilitas, transparansi, dan partisipasi. Transparansi adalah memberikan informasi keuangan yang terbuka dan jujur kepada masyarakat berdasarkan pertimbangan bahwa masyarakat memiliki hak untuk mengetahui secara terbuka dan menyeluruh atas pertanggungjawaban pemerintah dalam pengelolaan sumber daya yang dipercayakan 
kepadanya dan ketaatanya pada peraturan perundanag-undangan (Fierda, 2015).

Sedangkan akuntabilitas adalah pertanggungjawaban pengelolaan sumber daya serta pelaksanaan kebijakan yang dipercayakan kepada entitas pelaporan dalam mencapai tujuan yang telah ditetapkan secara periodik (Halim, 2012). Akuntabilitas dan transparansi merupakan satu bagian penting dalam pemberian informasi dan pertanggungjawaban atas pengelolaan dana publik kepada pemerintah. Sistem akuntabilitas ini harus sejalan dengan sifat transparansi, supaya tepat sasaran dan bisa terealisasi pembangunan untuk masyarakat berjalan dengan lanacar, berhasil, dan bisa dipertanggung jawabkan. Serta untuk mencegah pelanggaran hak asasi manusia (HAM), dan menuntaskan praktek korupsi, kolusi, dan nepotisme (KKN) (LAN dan BPKP, 2000).

Penelitian terdahulu tentang dana desa sudah pernah dilakukan, diantaranya penelitian Kartika dkk, (2016) tentang akuntabilitas pengelolaan dana desa (DD) di Desa Pemagutan Kaja Kecamatan Denpasar Utara. Hasil penelitian menunjukkan bahwa pengelolaan Dana Desa Tahun 2016 di Desa Pemecutan Kaja kurang akuntabel. Hal ini dilihat dari tiga indikator akuntabilitas keuangan yang digunakan yaitu transparansi, akuntabilitas, dan prinsip value of money belum terpenuhi dalam pelaksanaan pengelolaan Dana Desa Tahun 2016. Penelitian Nafidah dan Anisa (2017) tentang akuntabilitas pengelolaan keuangan desa di Kabupaten Jombang. Hasil penelitian menunjukkan bahwa pengelola keaungan desa di kabupaten Jombang yakni di Desa Sumbermulyo, Desa Bareng, dan Desa Kauman mulai dari tahap perencanaan, pelaksanaan, pelaoran dan pertanggungjawaban menunjukkan sudah dikelola secara akuntabel.

Ada penelitian Risya dan Nurodin (2017) tentang pengaruh transparansi dan akuntabilitas terhadap pengelolaan keuangan desa. Hasil penelitian menjelaskan bahwa transparansi berpengaruh terhadap pengelolaan keuangan desa. Hal ini dikarenakan pemerintah desa telah berupaya melaksanakan perinsip transparansi dalam pengelolaan keuangannya. Adapun adanya pengaruh akuntabilitas terdapat pengelolaan desa, karena pemerintah desa sebagai entitas pelaporan tealah merealisasikan prinsip akuntabilitas. Kemudian adan penelitian Alfasadun dkk. (2018) tentang transaparansi dan akuntabilitas pengelolaan dana desa. Hasil penelitian menunjukksn bahwa pemerintah wilayah kecamatan Kesesi kabupaten Pekalongan sudah menjalankan tahap perencanaan, pelaksanaan, penatausahaan, pelaporan, dan tanggungjawab dengan baik dan benar. 
Kemudian penelitian Susliyanti (2017) tentang transaparansi dan akuntabilitas ADD di Desa Trimulyo Kecamatan Bantul. Hasil penelitian menjelaskan bahwa desa Trimulyo kabupaten Bantul telah melaksanakan program ADD dengan prinsip transparansi, akuntabilitas, dan partisipatif dengan sangat baik. Berdasarkan analisis efektifitas ADD sangat efektif yaitu sebesar 100\%, selain itu ADD memberi kontribusi sebesar 55,62\% dari total pendapatan yang diterima pemerintah Desa Trimulyo.

Beberapa penelitian di atas terdapat kesamaan dengan penelitian saat ini karena sama-sama meneliti tentang pengelolaan ADD. Penelitian sama-sama bertujuan untuk mengetahui realisasi tingkat Transparansi dan Akuntabilitas ADD, akan tetapi metode analisis yang digunakan berbeda dengan peneliti saat ini yaitu jenis penelitian yang digunakan deskriptif kualitatif dengan bertujuan untuk menilai pengelolaan keuangan desa dengan mengguanakn asas transparansi dan akuntabilitas pengelolaan ADD khususnya dalam hal perencanaan, pelaksanaan, pengawasan dan pertanggungjawaban.

Tidak jauh berbeda dari tujuan para peneliti terdahulu yang melakukan penelitian tentang bagaimana penerapan transparansi dan akuntabilitas ADD. Peneliti juga tertarik melakukan penelitian di desa Wakan Kecamatan Jerowaru Lombok Timur. Untuk diketahui bahwa transparansi dan akuntabilitas pemerintahan desa dalam pengelolaan ADD, pemerintah Desa harus berusaha agar tepat sasaran sehingga dapat digunakan untuk kepentingan pembangunan dan pemberdayaan masyakat didesa tersebut. Oleh karena itu tujuan penelitian ini adalah untuk menganalisis bentuk-bentuk transpransi dan akuntabilitas pengelolaan ADD di Desa Wakan Lombok Timur.

\section{Metode Penelitian}

Dalam penelitian menggunakan metode penelitian kualitatif dengan pendekatan deskriptif. Metode penelitian kualitatif adalah metode penelitian yang berlandaskan pada filsafat postpositivisme, digunakan untuk menilai pada kondisi obyek yang alamiah, (sebagai lawannya adalah eksperimen) dimana peneliti adalah sebagai instrumen kunci, teknik pengumpulan data dilakukan secara triangulasi (gabungan), analisis data bersifat induktif/kualitatif, dan hasil penelitian kualitatif lebih menekankan makna dari pada generalisasi (Sugiyono, 2014: 9). Penelitian deskriptif adalah salah satu jenis penelitian yang tujuannya untuk menyajikan gambaran lengkap mengenai setting sosial atau dimaksudkan untuk eksplorasi dan klarifikasi mengenai satu fenomena atau kenyataan 
sosial. Penelitian ini dilakukan untuk dapat mengungkap peristiwa dan fakta-fakta yang berkaitan dengan transparansi dan akuntabilitas dalam pengelolaan ADD.

Adapun informan untuk mengetahui tingkat transparansi pengelolaan ADD dalam penelitian ini, yaitu masyarakat yang diwakili oleh, tokoh masyarakat, dan tokoh agama, dan Badan Permusyawaratan Desa (BPD) sebagai suatu sumber data karena pihak tersebut memiliki garis koordinasi dengan pemerintah desa dan punya fungsi mengevaluasi dan menyampaikan aspirasi dari masyarakat. Sedangkan informan untuk mengetahui tingkat akuntabilitas pengelolaan ADD dalam penelitian ini yaitu aparatur Desa Wakan Kecamatan Jerowaru Kabupaten Lombok Timur yakni, kepala desa, sekertaris desa, bendahara desa, kasi kesejahteraan, kasi kepemerintahan, dan kaur perencanaan.

Dalam penelitian ini, peneliti membahas tentang transparansi dan akuntabilitas dalam pengelolaan ADD di Desa Wakan Lombok Timur. Adapun jenis deskripsi data yang disajikan meliputi perencanaan, pelaksanaan, dan pertanggungjawaban ADDdi Desa Wakan. Adapun data dalam penelitian ini diperoleh dari menyusun dan pengelompokan data yang didapatkan dari wawancara. Peneliti menggunakan wawancara untuk mengetahui apakah Desa Wakan sudah transparansi dan akuntabilitas dalam hal perencanaan, pelaksanan, dan pertanggungjawaban ADD. Teknik analisis data dilakukan melalui tahapan reduksi data, penyajian data, dan penarikan kesimpulan.

\section{Pembahasan}

\section{Profil Desa Wakan Lombok Timur}

Desa Wakan merupakan salah satu desa dari 3 (Tiga) Desa Pemekaran yang sudah didifinitifkan melalui Perda Nomor 15 Tahun 2010 dan ada di Kecamatan Jerowaru. Desa ini merupakan Desa terkecil dengan luas 832,1 Ha. Atau 83,21 Km², yang terdiri dari 14 (Empat Belas) Dusun. Jumlah penduduk di Desa Wakan saat ini yaitu mencapai 6.851 jiwa, dari jumlah penduduk tersebut terdapat 3.403 Laki-laki dan 3.448 perempuan. Di Desa Wakan memiliki penduduk miskin sebanyak 896 jiwa. Mata pencaharian masyrakat Desa Wakan yang mendomenasi adalah bermata pencaharian di sektor pertanian sebanyak 2004 jiwa,dan sisanya bekerja bekerja di sektor non pertanian yakni buruh tani 628 jiwa, pedagang 95, PNS 20 jiwa, sopir 15, karyawan swasta 47 jiwa, tukang kayu/batu 343 jiwa, pengerajin 9 jiwa, dan guru 58 jiwa (Profil Desa, 2019). 
Desa Wakan saat ini memiliki 14 kepala wilayah (kawil), 57 rukun tetangga (RT), dan memiliki jumlah penduduk sebanyak 6.851 jiwa (Profil Desa, 2019). Hal ini tidak bisa dianggap remeh seiring dengan bertambahnya jumlah penduduk dan pemekaran wilayah. Dalam hal ini bertujuan untuk mendapatkan pelayanan serta memudahkan masyarakat dalam hal pengurusan administrasi pemerintahan.

\section{Transparansi Pengelolaan Alokasi Dana Desa}

\section{Tahap Perencanaan}

Dalam merencanakan suatu kegiatan dari dana seperti ADD harus benar-benar diperhatikam untuk kebutuhan masyarakat semata, dikarenakan ADD merupakan salah satu sumber dana pendapatan desa. Sehingga dalam penggunaan ADD harus benar-benar direncanakan dalam penyusunan APBD yang di bahas ditingkat desa sehingga disepakati bersama oleh pemerintah desa dan BPD yang merupakan perwakilan bagi masyarakat desa yang nantinya dijadikan pedoman untuk kegiatan pembangunan desa. Dalam tahap perencanaan, diperlukan dari prinsip partisifatif dari masyarakat untuk ikut serta dalam suatu perencanaan baik secara langsung atau perwakilan dari lembaga yang mewakili kepentingan masyarakat. Menurut informan pengelolaan dana desa bahwa alam mewujudkan suatu prinsip tranparansi dalam proses prencanaan pengelolaan ADD adalah pertama musyawarah dusun, musyawarah desa atau rapat besar. Adapun yang menghadiri yaitu dari semua unsur lembaga dan amparatur desa di Wakan. Untuk mekanisme perencanaan kita mulai dari musyawarah dusun terus lanjut ke musyawarah desa. Keseluruhan dari berbagai unsur masyarakat dan semua aparatur desa yang ada di desa Wakan (Wawancara, Sarijul Basri, 23 Juli 2020).

Adapun pemaparan jawaban dari pertanyaan yang sama dijelaskan bahwa untuk perencanaan pembangunan dimulai dari pas mengadakan musrembang, selanjutnya baru dimasukkan ke dalam APBD. Bentuk mekanisme untuk pengelolaan adalah TPK dan selanjutnya diawasi oleh PTPKD. Untuk pembayaran barang dilakukan oleh bendahara desa. Adapun yang menghadiri musrembang adalah RT, LKMD, dan PKK (Wawancara, Saiful Bahri, 26 Juli 2020). Dalam perencanaan dimulai dari musyawarah desa dan dihadiri oleh semua elemen yang ada di desa. Selanjutnya perencanaan RKP ditingkat desa untuk usulan dari masing-masing dusun untuk dimasukkan pada musrembang. Untuk mekanisme sendiri pemerintah desa melakukan pengeloalaan ADD dimulai dari musyawarah desa hingga lanjut pada musrembang. Peserta yang hadir adalah semua unsur dan lembaga yang ada disesa yakni BPD, Kawil, RT, dan LKMD (Wawancara, M. Hamdi, 26 Juli 2020). 
Dalam tahap perencanaan sudah sesuai dengan sifat transparan atau sudah sesuai dengan aturan. Dimulai dengan musyawarah dusun hingga musyawarah desa. Dari semua unsur dan elemen lembaga yang ada di desa. Padangan tokoh agama dan tokoh masayarakat (Wawancara, Masrun dan Shalihuddin, 23 Juli 2020). Jika untuk musyawarah dengan masyarakat jarang sekali, biasanya cukup dengan aparatur desa dengan LKMD, dan BPD. Melakukan musyawarah, tetapi apakah masyarakat bisa dilibatkan langsung apa tidak dalam hal tersebut. Yang hadir cuma aparatur desa dan lembaga seperti BPD dan LKMD. Pemerintah desa kurang transparan untuk menyampaikan informasi ataupun hasil dari musrembang tersebut. Dalam mengadakan musyawarah kami jarang diundang dalam musyawarah tersebut. Dalam mengikuti musyawarah hanya lembaga dan elemen yang ada di desa saja, sedangkan tokoh masyarakat jarang diundang dalam hal tersebut.

Dijelaskan bahwa pada tahap perencanaan ADD sudah dilakukan sudah sesuai dengan prinsip Transparansi dengan partisipasi dari masyarakat, hal ini dapat dilihat pemerintah desa sebelum dilaksankannya suatu kegiatan pemerintah desa melakukan musyawarah dengan masyarakat pada musyawarah di tingkat dusun (Musdus) hingga musyawarah tingkat tertinggi desa yakni Musrembang dalam hal mebahas dari perencanaan pembangunan. Untuk penerapan dari sistem transparansi pengelolaan ADD, pada tahap pengumpulan data serta informasi pada saat penelitian di Desa Wakan, bahwa keuangan desa sudah dikelola dengan baik berdasarkan dari asas trasparansi (keterbukaan), bisa dilihat dari hasil laporan mengenai tingkat persentase kehadiran yaitu 90\%. Dari hasil persentase tersebut bisa dilihat dari kepedulian atau kesadaran dari masyarakat Desa Wakan untuk mengambil peran aktif untuk pengelolaan pembangunan sudah cukup baik.

\section{Tahap Pelakasanaan}

Dalam pelaksanaan kegiatan yang biayanya dari ADD dalam hal ini dilaksanakan oleh tim pelaksanaan desa, untuk program dari ADD ini yang dilakukan oleh kepala desa untuk mendukung keterbukaan informasi dari program ADD yaitu dengan memasang papan informasi didepan kantor desa yang berisikan program pelaksanaan dari kegiatan fisik berupa baliho. Pemerintah desa melakukan hal tersebut dalam rangka mewujudkan prinsip transparansi dan partisipatif dalam pembangunan desa, sehingga masyarakat bebas dalam mengakses informasi tentang program dari ADD tersebut serta masyarakat bisa memberi masukan atau keritikan kepada pengelola untuk mewujudkan keefektifan dalam pengelolaan ADD. 
Pemerintah desa membuat baliho terkait pengumuman APBD, kemudian dibagikan copyan APBD ke masing-masing kawil dan RT untuk disosialisasikan kemasyarakat. Untuk dipajangkan baliho rincian dari APBD tersebut yaitu bagian dari bentuk sosialisasi kemasyarakat. Langsung melaksanakan perencanaan sesuai berdasarkan APBD (Wawancara, Sarijul Basri, 23 Juli 2020). Dalam hal ini pemerintah desa sangat berperan dalam menerima usulan masyarakat, sehingga usulan tersebut dibahas dalam musrembang. Dalam melaukan keterbukaan, pemerintah desa dalam menginformasikan dengan jumlah yang dana diterima melakukan dengan prinsip transparansi. Untuk pelaksanaan pembangunanya dengan menjalankan sesuai dengan APBD (Wawancara, Saiful Bahri, 26 Juli 202). Menurut saya cukup baik, karena setiap ada musyawarah terkait jumlah penerimaan ADD dan dana yang lain pemerintah desa membuat informasi melalui papan informasi desa. Keterbukaan informasi dari program ADD yaitu dengan memasang papan baliho terkait dengan anggaran dari penerimaan ADD. Peserta yang hadir adalah semua unsur dan lembaga yang ada di desa yakni BPD, Kawil, RT, dan LKMD (Wawancara, M. Hamdi, 26 Juli 2020).

Dalam pandangan berbeda dari BPD, BPD kadang hanya hanya sebagai moderator dalam penunjukan dan pelaksanaan ADD dimana sebagai TPK sekaligus mengawasi. Proses dilakukan melalui musyawarah seperti, musrembang yang biasa dihadiri oleh perwakilan. Dari pelaksanaan sendiri, sesuai dari program yang sudah direncanakan bersama pada saat musyawarah (Wawancara, Abdul Wahid, 22 Juli 2020). Kalau dilihat pemerintah desa sudah cukup baik dan sudah cukup terbuka kepada masyarakat, karena setiap informasi pemerintah desa selalu diinformasikan baik melalui papan penguman atau baliho. Setiap ada penerimaan atau pemasukan dana selalu disampaikan kepada masyarakat baik melaui kawil atau RT. Kami menjalankan sesuai rencana bersama dari program yang telah di rencanakan. Peran pemerintah desa masih kurang baik kepada masyarakat, karena kurangnya keterbukaan menyampaikan informasi secara menyeluruh untuk masyarakat desa wakan. Dalam hal trnsparansi pemerintah masih kurang efektif dalam menyampaikan informasi terkait program yang akan dilaksanakan dan anggaran untuk pelaksanaan kegiatan masih kurang jelas. Masih kurang sesuai dengan apa yang sudah direncanakan (Wawancara, Masrun dan Shalihuddin, 23 Juli 2020).

Dalam tahap pelaksanaan dari setiap kegiatan dan program dalam hal ini bersumber dari ADD menunjukkan 90\% sudah sesuai dengan peraturan yang belaku, yang artinya 
dalam hal pealaksanaan ADD telah melaksanakan dari prinsip transparansi. Sehingga pemerintah desa dalam menyampaikan informasi dengan secara jelas kepada masyarakat dengan membuatkan papan informasi sebagai salah satu dari bentuk sosialisai supaya masyarakat dapat mengetahui dari program ADD digunakan untuk apa saja. Secara fisik dan administrasi dapat dipertanggungjawabkan dengan baik dan benar sesuai dengan prinsip akuntabilitas dan dengan prosedur yang sudah berlaku.

Dalam pelaksanaan dari prinsip akuntabilitas tersebut, pemerintah desa membuat laporan pertanggungjawaban ADD yang di ambil dari laporan realisasi pelaksanaan APBDesa. Untuk hal pelaksanaan dari program ADD yakni, dalam tahap pelaporan pemerintah desa sudah melakukan pertanggungjawaban dalam pelaksanaan program ADD dan APBDes kepada pemerintah pusat yang dilakukan secara periode.

\section{Akuntabilitas Pengelolaan ADD}

Akuntabilitas menurut Peraturan Perundang-Undangan Nomor 6 Tahun 2014 tentang Desa adalah asas yang menetukan bahwa setiap kegiatan dan hasil akhir kegiatan penyelenggaraan pemerintah desa harus dapat dipertanngungjawabkan kepada masyarakat desa sesuai dengan ketentuan perundang-undangan. Oleh karena itu, pengelolaan ADD merupakan sumber pendapatan desa yang paling utama yang harus dipertanggungjawabkan dengan transparansi kepada masyarakat dan pemerintah pusat sebagai pemberi kewenangan atau sumber anggaran. Dalam pertanggungjawaban Desa Wakan terhadap ADD di sertakan pada petanggungjawaban pada APBD. Dalam mempertanggungjawabkan suatu pelaksanaan dari program ADD kepada pemerintah pusat melalui pelaporan dan pertanngungjawaban pengelolaan ADD kepada masyarakat dalam hal ini berbentuk fisik.

Pelaksanaan alokasi ADD diawasi oleh BPD, sehingga bentuk pertanggungjawaban harus sesuai dengan yang sudah direncanakan di APBD sampai dilakukannya pertanggungjawaban. Jenis pelaporan harus sesuai dengan Siskudes yang sudah ditentukan oleh pusat. Dilaporkan secara langsung ke pusat dan pelaporan berbentuk softcopy juga. Pelaporan biasanya sesuai dengan target yang sudah direncanankan yang mana hal ini bisa dilihat dari kepuasan masyarakat (Wawancara, Sarijul Basri, 23 Juli 2020). Dalam tahap pertanggungjawaban untuk pelaporanya berbeda, mulai dari tahun 2017 pelaporannya secara online tidak seperti 2016 pelaporanya berbentuk manual. Jenis pelaporanya langsung dari TPK, bendahara langsung yang memberikan pembayaran. 
Sampai saat ini, dari pekerjaan fisik sudah sesuai, seperti kemarin kita menyewa molen untuk pembangunan rabat jalan (Wawancara, Saiful Bahri, 26 Juli 2020).

Semua bentuk pertanggungjawaban harus sesuai dengan perencanaan yang sudah ada di APBD itulah yang akan dipertanggungjawabkan. Menurut saya pribadi sudah sesuai dengan target, dilihat dari kepuasan masyarakat sampai saat ini belum ada yang komplin (Wawancara, M. Hamdi, 23 Juli 2020). Pengelolaan dana desa harus sesuai dengan bidang masing-masing. Semua jenis laporan kegiatan yang ada di desa, semua LPJ diserahkan langsung. Bisa dikatakan sudah sesuai, kalau dilihat dari infrastrukturnya yang sudah direncanakan sebelumnya (Wawancara, Abdul Wahid, 22 Juli 2020). Dalam pertanggungjawaban seperti biasa, tetap melaporkan hasil dari program atau kegiatan. Untuk pertanggungjawaban, rata-rata pemerintah desa sudah berkompeten. Kalau dilihat dari segi infrastrukturnya, untuk pekerjaannya sudah sesuai dengan yang sudah direncanakan bersama. Dalam tahap pertanggungjawaban sudah dikatakan cukup baik. Selalu melaporakan dari kegiatan atau program yang sudah dibuat. Dari hasil pelaksanaan ADD dengan yang sudah direncanakan sebelumnya sudah sesuai dengan prinsip akuntabel (Wawancara, Masrun dan Shalihuddin, 23 Juli 2020).

Dilihat dari sisi akuntabilitas, pemerintah Desa Wakan dalam pelaksanaan ADD sudah melaksanakan prinsip auntabiliatas dalam hal ini didukung dari penerapan lapangan yakni pertanggungjawaban dari segi fisik dan administrasi sudah cukup baik sesuai dengan perundang-undangan. Dari hasil wawancara kepada informan yang dilakukan oleh peneliti menunjukkan bahwa pertanggungjawaban APBDes di Desa Wakan sudah baik, bisa dilihat dari segi fisik dana administrasi sudah sesuai berdasarkan hasil persentase mencapai $100 \%$ dan dapat dikatakan bahwa sistem akuntabilitasnya sudah sangat baik.

\section{Kesimpulan}

Transparansi dan akuntabilitas dalam pengelolaan ADD untuk menyejahterakan penduduk di Desa Wakan Lombok Timur sudah dilakukan dengan baik. Pengelolaan ADD dalam tahap perencanaan, pelaksanaan, dan pertanggung jawaban sudah dilaksanakan dengan cukup baik. Hal ini dapat dilihat pembuatan informasi dari kegiatan atau program yang sumbernya dari ADD. Pertanggungjawaban secara fisik dan administrasi sudah cukup baik sesuai dengan peraturan perundang-undangan yang 
berlaku.

\section{Daftar Rujukan}

Alfasadun, A., Hardiningsih, P., \& Srimindarti, C. (2018). Transparansi Dan Akuntabilitas Pengelolaan Dana Desa. Proceeding SENDI_U. Retrieved from https://unisbank.ac.id/ojs/index.php/sendi_u/article/view/6051.

Andrianto, Nico. (2007). Good e-government: transparansi dan akuntabilitas publik melalui e-government. Malang: Bayumedia.

Databoks. (2019). APBN 2018, Pemerintah Alokasikan Dana Desa Rp 60 Triliun. (OnLine) Valiable https://databoks.katadata.co.id. Diakses tanggal 2 April 2019.

Fierda, Shafratunnisa. (2015). Penerapan Prinsip Transparansi dan Akuntabilitas Dalam Pengelolaan Keuangan Kepada Stakeholders di SD Islam Binakheir, Skripsi. Jakarta: UIN Syarif Hidayatullah.

Halim, Abdul. 2007. Akuntansi Sektor Publik: Akuntansi Keuangan Daerah. Jakarta: Salemba Empat.

Halim, Abdul. 2012. Pengelolaan Keuangan Daerah. Edisi Ketiga. Yogyakarta: UPP STIM YKPN.

Kartika, A., Yasintha, P. N., \& Wismayanti, K. W. D. (2018). Akuntabilitas Pengelolaan Dana Desa Tahun 2016 (Studi Kasus: Desa Pemecutan Kaja, Kecamatan Denpasar Utara). Jurnal Akuntansi Program S1, 1(1).

LAN dan BPKP. (2000). Akuntabilitas dan Good Governance: Modul Sosialisasi Sistem Akuntabilitas Kinerja Instansi Pemerintah, LAN BPK RI. Jakarta.

Miftahuddin. (2018). Akuntabilitas dan Transparansi Pemerintah Desa Terhadap Pengelolaan Dana Desa di Desa Panggungharjo Kecamatan Sewon Kabupaten Bantul. Skripsi. Yogyakarta: Universitas Islam Indonesia.

MPR RI, (1998). Tap MPR No.XV/MPR/1998 tentang Penyelenggaraan Otonomi Daerah. Jakarta: MPR RI.

Nafidah, L. N., \& Anisa, N. (2017). Akuntabilitas pengelolaan keuangan desa di kabupaten Jombang. Jurnal Ilmu Akuntansi, 10(2), 273-288.

Peraturan Bupati Lombok Timur Nomor 2 Tahun 2018 tentang Pedoman Penyusunan Anggaran Pendapatan dan Belanja Desa Tahun Anggaran 2018.

Peraturan Bupati Lombok Timur Nomor 21 Tahun 2013 tentang Pedoman Pengelolaan Alokasi Dana Desa.

Peraturan Menteri Dalam Negeri Nomor 20 Tahun 2018 tentang Pengelolaan Keuangan Desa.

Peraturan Menteri Dalam Negeri Nomor 37 Tahun 2007 tentang Alokasi Dana Desa.

Peraturan Menteri Keuangan Republik Indonesia Nomor 49 Tahun 2016 tentang Tata Cara Pengalokasian, Penyaluran, Penggunaan, Pemantauan Dan Evaluasi Dana Desa.

Peraturan Pemerintah Republik Indonesia Nomor 60 Tahun 2014 tentang Dana Desa 
Yang Bersumber dari Anggaran Pendapatan dan Belanja Negara (APBN).

Risya, U., \& Nurodin, I. (2017). Pengaruh Transparansi dan Akuntabilitas terhadap Pengelolaan Keuangan Desa. Jurnal Ilmiah Ilmu Ekonomi (Jurnal Akuntansi, Pajak dan Manajemen), 6(11), 74-80.

Susliyanti, E. D. (2017). Transparansi Dan Akuntabilitas Alokasi Dana Desa (Studi pada Desa Trimulyo, Kecamatan Jetis, Kabupaten Bantul Tahun 2015). Wahana: Jurnal Ekonomi, Manajemen dan Akuntansi, 20(1), 16-26.

Undang-undang Republik Indonesia Nomor 22 Tahun 1999 tentang Pemerintahan Daerah Undang-undang Republik Indonesia Nomor 23 Tahun 2004 tentang Pemerintahan Daerah.

Undang-undang Republik Indonesia Nomor 23 Tahun 2014 tentang Pemerintahan Daerah

Undang-undang Republik Indonesia Nomor 32 Tahun 2004 tentang Perimbangan Keuangan antara Pemerintah Pusat dan Pemerintahan Daerah

Undang-undang Republik Indonesia Nomor Nomor 25 tahun 1999 Perimbangan Keuangan Antara Pemerintah Pusat Dan Daerah

Undang-undang Republik Indonesia Nomor Tahun 2015 Penetapan Peraturan Pemerintah Pengganti Undang-Undang Nomor 1 Tahun 2014 Tentang Pemilihan Gubernur, Bupati, Dan Walikota Menjadi Undang-Undang.

Wawancara, Abdul Wahid, 22 Juli 2020.

Wawancara, M. Hamdi, 23 Juli 2020.

Wawancara, M. Hamdi, 26 Juli 2020.

Wawancara, Masrun, 23 Juli 2020.

Wawancara, Saiful Bahri, 26 Juli 2020.

Wawancara, Sarijul Basri, 23 Juli 2020.

Wawancara, Shalihuddin, 23 Juli 2020. 